\title{
A Tragedy of Devil and Angel ----An analysis of the alienation of the character The Aunt in Moyan's novel The Frog
}

\author{
Lirong AN ${ }^{1}$, Shuhui SHI ${ }^{2}$ \\ ${ }^{1}$ Department of Chinese University of Nanjing, Jiangsu Province, China \& College of Humanities, Yili Normal \\ University, Yining, Xinjiang uygur autonomous region \\ ${ }^{2}$ College of Humanities, Yili Normal University, Yining, Xinjiang uygur autonomous region
}

\begin{abstract}
This thesis analyses the image of The Aunt in two periods of time, that is before and after the enforcement of China's birth control policy. In both periods the character is alienated, first as an angel and then as a devil. The reason why the very same person can be seen so differently is that she is too barbaric and crazy in carrying out the birth control policy made by the government.
\end{abstract}

Index Terms - Alienation; The Aunt; Tragedy.

Moyan's novel The Frog depicts a 60-year fluctuating childbearing history in People's Republic of China through the form of epistolary writing and drama, with The Aunt's life experience as a country obstetrician for more than 50 years. The readers may feel love and hate and sympathy at the same time towards the character The Aunt. The Aunt's life could be roughly divided into two periods: before and after the enforcement of China's birth control policy. In the two periods her job was different, in the first period a country obstetrician for the villagers and in the second period the executor of birth control policy forbidding the babies' coming, but actually the nature of her job was the same: to work for the government. The difference was in the content, that is to welcome new babies into the world or forbid their coming when it was against the nation's population policy. At that time people in the rural area had a persistent wish to bear sons, thus they kept giving birth to babies until a son was born. The Aunt's job was different in contents but of same nature thus it was not divided from her own perspective. The reason why she was a tragic character was that different people had different opinion towards the work she did. "From the ridge or peak, the views are different". The Aunt took both welcoming new babies coming and forbidding it worthwhile job as long as it was approved by the government, however the villagers in Gaomi Northeast Countryside had a different opinion. They thought her former job had great value and her later job not only valueless but also retrograde. The same thing means differently to different people because they all see it from their own perspective and thinking about their own interests thus the unity cannot be reached. That's why The Aunt's life a tragedy. Before the birth control policy came, The Aunt served her fellow villagers well in Gaomi Northeast Countryside and there was no conflict in their values. The readers can feel the harmony and beauty in the depiction in this period. Even when delivering animal babies like cattle, she was so loving thus people took her as an angle. After the birth control policy came, the conflict came also. The villagers really longed for having sons but The Aunt just stood in the way as the executor of the nation's birth control policy. Thus she was considered a devil now. Hostility from the villagers and betrayal from her family made her life tragic. In the following part, I will give a more detailed analysis of her life in the two periods.

\section{The Angel Aunt}

The description of The Aunt before the enforcement of birth control policy Gaomi Northeast Countryside is like this:" A women doctor galloping on the frozen river by bike; a women doctor carrying her medicine chest, holding an umbrella, advancing as she fighting a cluster of frogs with trousers rolled up; a women doctor who holds a baby with sleeves bloody and laughs loudly ......" She started her delivering career since the age of seventeen and went through a lot. During the Anti-Japanese War, she lived in Pingdu city for three months and showed undaunted spirit when facing dangers. In Gaomi Northeast Countryside, she was very influential and admired, and she was also content with the pleasure coming along with her service to others. She delivered countless babies and was not only considered as an able women, but also deified as a Bodhisattva, a child-sending goddess, an angel. With such halos around her, people even think she can determine the gender of the baby. The angel Aunt was an authentic worker for the party in the eyes of her fellow villagers at this moment. "People are so busy with getting pregnant and giving birth to new lives. "In such social context her work for the government was also work for her fellow villagers and in the work she found self-fulfillment. The villagers were grateful to her with which she was content. She was a responsible obstetrician from the age of seventeen, and that sense of responsibility drove her to get devoted in her job. Her love, tenderness and courage could be perceived even when delivering cattle. She showed fine sentiments and due respect and awe to new life.

Her romantic relationship went smoothly for the time being also. The "I", an important role in the book, a playwright, Little Tadpole, often felt proud of his future unclein-law Wang Xiaoti, who was a pilot and presented his aunt Enicar watch. But from the beginning this Wang Xiaoti with a petty bourgeoisie flavor and The Aunt were actually on different paths, thus the destiny of her romantic life was doomed. It was said that he fled to Taiwan because he got a crush on "Rose in the Night Sky" whose voice was so sweet and attractive. Thanks to this man, The Aunt was placed on probation within the Party. The author did not mention her 
first love and there seemed to be no love between The Aunt and Wang Xiaoti, thus the character The Aunt was not rich enough since her emotional life basically gave way to her frantic devotion to her job for the Party. Later in her blood writing she wrote that she hate Wang Xiaoti and there was no love left for him in her heart. She once said no matter alive or dead, her life belonged to the Party. We can say that her marriage was with the Party and there was not much room for romantic love. In the frantic devotion to her work which she paced above everything else she found content, pleasure and fulfillment, yet it was was also her undoing and a foreshadowing for her tragic life.

\section{The Devil Aunt}

When reflecting on the enforcement of China's birth control policy, the author gave a detailed descriptions of how The Aunt did her job in a crazy and barbaric way, which could make people's blood boil. Now she became a horrible killer, a devil who killed many innocent mothers and babies. Why China should carry out such a birth control policy? The following are some reasons we find: When a society's population is too big or too small, everyone in this society is to be effected in a harmful way. The demographers contends that there exists an appropriate amount of population for a society to be structurally whole and to function effectively. It takes the population of the whole community as the object of study and it is not only a theory. When the population moves away from this appropriate point, the harmful effects will show in the lives of the offspring. In a relatively fixed community, when there are too many children born, the problem how to get enough living resources emerge immediately. Parents should take providing enough financial and social living resources to their children into account. A sane society is required to meet that standard. If most people in a community cannot get enough living resources to live independently and to be responsible to their offspring, turbulence will be a sure result. To be not get involved in turmoil, the structure of the community has to be changed or there must be ways to supplement resources. In other words, the society should be able to ensure that the parents won't worry about how to bring their children up, or the society has not been in the best structure.

Ref. [1] Either the population should adjust itself to the social structure or social structure accommodate itself to the population, and usually the former is more convenient. So it demands some efforts for a community not in economic expansion to control the population.

From the discussion above, we can see that it was rational for China to carry out birth control policy. But why the villagers always wanted to have more babies until a son was born? An objective cause was that in the rural area, especially rural area in China not much mechanized at that time, manpower was still very important for agricultural production. A subjective reason was that the villagers were still deeply influenced by the conventional notion coming from the thousands years of feudal history that man is superior to woman. The combination of these reasons drove the villagers in Gaomi Northeast Countryside to try their best in the guerrilla warfare with The Aunt s to go against the nation's birth control policy. Even though the birth control policy is rational as we discussed above, the process of enforcement was so ridiculous and irrational. As a well-known country obstetrician, it was she who made men have ligation and pregnant women have abortion when the birth control policy came. There was blood everywhere: caterpillar track tractors, steel wire rope, aloud noise, pulling off big tree, intending to set fire to the house, the death of her nephew's wife Wang Renmei and her unborn child, the death of Zhang Quan's wife, the death of the dwarf Wang Dan, all these appalling scenes were quite shocking to the readers. All the heroes in the guerrilla warfare were defeated by The Aunt who showed rich experience and great sophistication in the process. Now the readers expected that The Aunt could fail in finding out the whereabouts of those pregnant women so that they and their babies could be safe. But contrary to the readers' expectation, no matter how well hid, The Aunt could find those people. Even the accomplice who took a fancy to Little Lion was helping her. Just as her nephew's wife Wang Renmei said, The Aunt was a loyal dog of the Communist Part $\mathrm{y}$ and would bite anywhere the Party pointed.......She really made it to belong to the Party no matter alive or dead and leave no illegal parents escape unpunished. This way of doing things ran in the opposite direction with humanism and when there was a conflict between human relations and morality and the will of the nation this deviation was more clearly shown in the novel.

The Aunt was alienated in the process of enforcing the birth control policy, and in alienation she got nothing left but work. She became indifferent, merciless and ruthless, even to her nephew Little Tadpole. Although aware that the death of many little lives was her contribution, she did not reflect how barbaric she was in her enforcement of the birth control policy until old age. In her old age all the babies aborted by her reappeared through the hands of Hao Dashou, and the frog croaks sounded like the crying of thousands of babies to her. The Aunt lived more in deep repent than in reality in her old age. When doing auscultation to Little Lion, her expression showed as if Little Lion was really pregnant and of course she was not. Perhaps deep in her consciousness she was hoping every woman can bear babies as she wishes.

The life story of The Aunt is a tragedy and like Luxun has said, tragedies destroy the valuable things of life in front of people so the audience can feel a sense of grief and awe, thus catharsis happened.

The fifth part of the novel is presented in the form of drama. After the birth control policy was approved, those of wealth and position were still giving birth to more babies, and the child of Little Tadpole's coming into the world was a defiance and revolt against the policy. The more radical and fundamental a thought is, the more it goes into the deep root of all beings, the more thoughtful it is. ${ }^{[2]}$ The attitude this novel takes is quite radical, and this attitude says something about the nature of the whole story----the most important thing is to show respect to life. 
In the end I would like to talk about the two different forms this book takes, letter and drama. The drama surely expand the expressive force of space but it is kind of abrupt. Besides, the two form does not seem to integrate well to me. However, one flaw cannot obscure the splendor of the jade, and the novel still reads rather powerful and touching.

\section{References}

[1] Xiaotong Fei, "Fertility system," The Commercial Press, January 2008. pp. 200.

[2] Martin. Heidegger "Fertility system," "On the Way to Language," The Commercial Press , May 1997

[3] Moyan, "The Frog system," Shanghai Literature \& Art Press , October 2012 